\title{
Titel/Title: Bypassing Obstacles to Access: How NGOs Are Taken Piggy-Back to the UN
}

Autor*innen/Author(s): Kerstin Martens

Veröffentlichungsversion/Published version: Postprint

Zeitschriftenartikel/Journal article

\section{Empfohlene Zitierung/Recommended citation:}

Martens, Kerstin (2004): Bypassing Obstacles to Access - How NGOs are taken

Piggy-Back to the UN. In: Human Rights Review, 5, 80-91.

Verfügbar unter/Available at:

(wenn vorhanden, bitte den DOI angeben/please provide the DOI if available)

This is a post-peer-review, pre-copyedit version of an article published in Human Rights Review. The final authenticated version is available online at: https://doi.org/10.1007/s12142-004-1010-8

Zusätzliche Informationen/Additional information:

The author can be contacted at: martensk@uni-bremen.de 


\title{
Bypassing Obstacles to Access: How NGOs Are Taken Piggy-Back to the UN
}

\author{
Kerstin Martens
}

INTRODUCTION $^{1}$

Over the last decade, non-governmental organisations (NGOs) have become prominent players on the international scene, which seek to shape the proceedings and outcomes of international processes (della Porta et al 1999; Mathews 1997; Smith et al. 1997; Salamon 1994). A large number of NGOs today are active at the outside of political negotiations and show their dissatisfaction with governmental policies. Most visibly, during the protests against globalisation their capacity for mobility, networking across borders, and raising awareness, often within a short period of time, has clearly been revealed (Smith 2002; Khagram et al. 2002). However, many NGOs are also involved in the design of programs directly and shape political processes from the inside of the official arenas. Today, in fact many of them aim at working together with intergovernmental organisations (IGOs), of which the United Nations (UN) has become their major target (Anheier et al. 2002: 5; Smith et al. 1998: 396).

Such increasing involvement of NGOs on the global stage has been acknowledged in theoretical terms in the social sciences. International relations theory has been extended to societal actors when scholars recognised non-governmental activity in turning away from state-centric perspectives to society-dominated views on world politics. Over the last couple of years a number of valuable theoretical approaches have been developed which explain how NGOs exercise influence on the international stage. The "new transnationalists", for example, examined the conditions under which NGOs gain influence on state institutions and intergovernmental organisations (Risse-Kappen 1995). Others translated NGO participation in transnational relations into the concept of "world culture" in which NGOs play the dominant role (Boli \& Thomas 1999). Again others developed approaches of public private partnerships between societal actors and governments or business (Osborne 2000; Vaillancourt 2000).

Particularly influential, Keck and Sikkink identified a boomerang pattem by which advocacy networks including NGOs bypass state blockages (Keck \& Sikkink 1998). While Keck and Sikkink emphasised alliances between national $(\leftarrow \mathbf{p .}$ 80) NGOs, international NGOs and states to bypass norm-violating states and their blockages, in this paper I will draw the attention to the links of national NGOs with international NGOs and IGOs to get around the barrier against the pressure from societal actors on norm violating states. Such links are taken into consideration in the Keck and Sikkink model, however, their empirical relevance has been underestimated and will be strengthened through this paper. For the purposes of this article, special attention is drawn to formal arrangements for NGO consultation at the UN as such conditions are the first hurdle for NGOs to gain access to the IGO when they want to participate within its forum.

In the empirical part I thus need to first present general developments of NGO access to the UN so that the following example can be put into place. In this con- text, some observations on

\footnotetext{
${ }^{1}$ I would like to thank an anonymous reviewer for helpful comments and Celia Enders and Jegapradepan Arumugarajah for their assistance in preparing this paper.
} 
consultative status at the UN and its revision in 1996 will be provided to explain functions and mechanisms of formal NGO accreditation to the UN. Following on from that, I will show how national NGOs link up with international NGOs to use their channels to the UN. By doing so, it will be demonstrated how an NGO is able to bypass obstacles to access to the UN by being taken "piggy-back" through the consultative status of an international NGO. As an example, I focus on the International Federation of Human Rights (FIDH) and its new affiliate Human Rights in China (HRIC) to make the case particularly clear. By providing some insight of this example, more in-depth empirical evidence is brought forward about how the boomerang model works in relation to IGOs.

The ironic paradox hereby is that since the revision of accreditation processes for NGOs in 1996, for the first time, national NGOs are allowed to apply for consultative status which before was reserved for international NGOs only ${ }^{2}$; nonetheless, due to how the application to consultative status works in practice, national NGOs, in fact, are more than ever dependent on their international partners to receive access to the UN. The analysis is based on the examination of UN documents on NGO status and NGO material with reference to the UN. The bulk of information, however, has been gained through semi-standard expert-interviews with NGO representatives to the UN and UN officials. ${ }^{3}$

\section{THE BOOMERANG MODEL AND ACCESS TO THE UN}

The boomerang model is a particularly precise model of how NGOs use IGOs as a "detour" to influence states. This model is a conceptual frame, which exposes how domestic NGOs form alliances with international groups and with IGOs in order to put pressure on the repressive state. Keck and Sikkink studied transnational advocacy networks and discovered a pattern by which domestic actors bypass the repressive state by finding international allies who bring pressure on the state in question from outside. Transnational advocacy networks are "those relevant actors working internationally on an issue, who are bound together by shared values, a common discourse, and dense exchange of information and services" (Keck \& Sikkink 1998: 2). National groups, domestic NGOs, and social movements $(\leftarrow$ p. 81) link up with international NGOs which then establish (or use already established) bonds with intergovernmental organisations or other states in order to put pressure on norm-violating states.

Thus, national NGOs gain significant value from working together with international NGOs,

\footnotetext{
${ }^{2}$ Although Art. 71 UN Charter theoretically always allowed national NGOs to be accredited to the UN "where appropriate", it was not applied in practice, because this phrasing was inserted for one specific case only. During the discussions on the UN Charter, the trade unions in the United States split into two organisations; one of them supported the World Federation of Trade Unions and was represented at the UN through this international NGOs, whereas the other would not have had any representation. As the United States did not want to take part in this conflict, the phrasing was the compromise to allow for both organisations to be represented at UN level. ${ }^{3}$ Interviews included: Antoine Madelin, FIDH Representative in Geneva (conducted in Geneva, 28 May 2002); Eleni Petroula, FIDH Representative in Geneva 1998-2000 (conducted in Geneva, 5 December 2000); Sara Guillet, FIDH representative in Geneva 1994-1998 (conducted in Paris, 14 June 2001 ); Beatrice Laroche, UN Liaison Person of Human Rights In China (conducted in Paris, 13 June 2001); a staff member of the UN Department of Economic and Social Affairs in New York (conducted in New York, 18 April 2001) [wishes to be referred to only in his professional function]; Philip Ackermann, German Permanent Mission to the UN and Member of the UN NGO Committee (conducted in New York, 6 April 2001); Iain Levine, AI Representative in New York 1997-2000 (conducted in New York, 16 February 2001); Joanne Weschler, HRW Representative in New York (conducted in New York, 27 February 2001); Loubna Freih, Associate HRW Representative in Geneva (conducted in Geneva, 30 May 2002); Carl Schieren, Conference of Non-Governmental Organisations in New York (conducted in New York, 20 March 2001).
} 
because such cooperation opens up more opportunities for activities. While their direct channel for pressuring their target state is blocked, national NGOs seek linkages to international NGOs to find ways around this barrier. Most importantly, through cooperation with internationally operating NGOs, domestic actors may be able to access the international sphere. In particular, international NGOs often maintain links to IGOs, such as the UN, because it is less difficult for them to receive access, as they more easily fulfil all criteria for recognition.

Often, IGOs provide rules and regulations for consultation with NGOs that regulate the access of non-governmental organisations and their representatives. Such consultative status is like the hurdle which NGOs have to climb before maintaining official relations with the UN. NGOs are interested in gaining consultative status at the UN, because this status provides them with several opportunities to obtain information and to promote their own interests. On a formal level, for example, the consultative status at the UN entitles NGOs to receive official documents, they might also be invited to conferences and meetings where they may be allowed to make statements on a particular issue, and the consultative status facilitates their access to the work of the regional and special committees.

But also on an informal level, the consultative status enables NGOs to advance their standpoints. By being granted official status, NGO representatives receive a pass and a badge that allows them to enter the official UN buildings. For this reason, they have the chance to get in contact with governmental delegates and other representatives. Such physical access, for example, enables NGOs to keep themselves informed about current decisions and allows them to lobby official representatives informally for their aims. In fact, these opportunities to meet with UN officials are often more effective than the official proceedings. As an NGO representative argues, "[a]t any UN meeting the discussions in the coffee lounges and corridors are as important as, if not more important than, the official speeches" (Cook 1996: 187). Moreover, the consultative status is an "official way" to participate within the international political system. The recognition by the UN implies acknowledgement as international actors (Ritehie 1996: 180; Bruckmeier 1997: 140). It provides the NGOs with a "label of international credibility" (Bettati 1986: 12) and it is therefore the legitimisation for other organs of the UN or other IGOs to have contact with these NGOs. However, even when fulfilling all the criteria set by the UN, NGOs have no legal claim to be admitted to consultative status (Lagoni 1995: 907).

The number of NGOs maintaining official relations with the UN has risen tremendously since the establishment of the accreditation scheme. When the consultative status was introduced in 1950, 48 NGOs were accredited to the IGO. In the late 1960s, the number of NGOs grew to 180 which were having official relations $(\leftarrow \mathbf{p .}$ 82) with the UN and until the early 1990 s, the figure of accredited NGOs gradually increased to 744 . Since the mid-1990, however, the number of consulting NGOs exploded and has reached 2,300 today (DESA 2003). Most dramatically, figures grew in 1998 when more than 500 new NGOs became enrolled at once. There are two main reasons for this enormous growth. First, in the aftermath of the UN conferences in the first half of the 1990s, many NGOs, which before only had informal relations with the UN, applied for consultative status in order to formalise their relations. Moreover, many other NGOs became aware of the UN and their possible relations with the IGO and also applied for the status.

Secondly, the various UN agencies, which sometimes have their own mechanisms for NGO accreditation, were asked to provide lists of NGOs, which then automatically became enrolled on the consultative status scheme. As a consequence, a main difficulty for NGOs to be accredited today is that the system has reached its "natural limits". With the opening of the consultative 
status to national NGOs and the increased awareness about NGO participation within the framework of the UN, the number of applications for consultative status has mushroomed. As a result, the system of NGO accreditation "imploded". The number of NGO applications has risen to 300 or 400 a year; the NGO Committee, however, can only deal with around 100 applications each annual session (UN Doc. E/1998/43). For this reason, NGOs have to wait for their application to be processed for several years now.

An important aspect of NGO accreditation for consultative status is the composition of the NGO Committee. It consists of 19 members who are representatives of their governments at the UN, following a geographical ratio, which allows for the various regions of the world to be represented. The composition of the committee takes place informally, thus, each regional group decides among itself about the representing nations to be on the committee. The seats on the committee rotate; each country serves for a period of four years, but there is no limit to multiple sequencing periods on the committee. Officially, the committee meets for two sessions of three weeks a year, but due to its increase in work, its sessions usually become extended by another three weeks.

For some states serving on the NGO Committee is of interest in order to influence the activity of NGOs on the international level. As the committee discusses all NGO related matters - it approves accreditation for the first time as well as changes of status, such as "upgrading", suspensions, and withdrawals - some states are particularly cautious and make sure that any NGOs which seek to undermine the state's authority, will not succeed with the application process. Thus, some countries are very aware of having a representative in the committee; for example, China and Cuba have been members of the committee for decades, and stopped successfully the applications of anti-Chinese and anti-Cuban NGOs. As a consequence, decisions in the committee can be highly political and depend on the political climate between the party states involved. As Lagoni pointed out, "[i]t is hardly surprising that the decision of the Council to make an arrangement with a particular non-governmental organisation or to place it on the Roster or, on the other hand, to $(\leftarrow \mathbf{p . ~ 8 3})$ suspend or withdraw its status may be influenced by political considerations" (Lagoni 1995: 907). As a result, the NGOCommittee is - as mentioned in an interview one of the most debated committees of the UN and, by many, it is regarded as the committee with the worst reputation.

Membership on the NGO Committee is not only useful to hinder NGO accreditation, it may also be a tool to bring in "governmental friendly" NGOs. Although the opening of the consultative status for national NGOs was intended to create more diversity within the NGO community, single governments make use of the new accreditation process for political purposes. They promote "their" national NGOs, which support governmental politics or they even create NGOs themselves only for having them associated with the UN. As an NGO representative reports, "looking closely at the reports of the Committee of NGOs since 1996, it can be seen that GONGOs [Government-Organised NGOs] from countries such as Cuba, Tunisia, China, Pakistan and India have obtained consultative status" (Petrula 2001: 53). She further describes the effects of such accreditations: "At the last sessions of the United Nations Commission for Human Rights, or of the Subcommissions for the Promotion and Protection of Human Rights, several GONGOs intervened to praise the level of respect for human rights in their countries, expressing support for government policies that had involved grave human rights violations, or denouncing human rights violations by neighbouring countries" (Petrula 2001: 53). These developments may - as some interviewees fear - undermine the whole system of NGO accreditation as it calls into question their credibility as independent societal actors. 
Complaints about NGOs can be made at any time throughout the year and need to be submitted to the NGO Committee which decides on them. Often country delegates search for reasons why to expel particular NGOs which are not well-considered in their country. In particular, some states observe NGOs intensely with regard to their behaviour and comments during the sessions of the Commission on Human Rights in order to seek NGO suspension when they do not follow the procedural rules. Very alarming for NGOs is also the period when the quadrennial reports about their activities with the UN are due, as governments tend to use this occasion to report incidents and form coalitions against single NGOs; the committee then decides on the grievance of these complaints. Under exceptional circumstance the committee can also ask for such a report from an individual organisation between the regular dates.

Moreover, there are some issue-areas in which accreditation is more difficult than in others. This particularly concerns NGOs involved in specific issue-areas or geographical regions. For example, NGOs involved in regional conflicts when one member of the NGO Committee is involved, are often under dispute. NGOs engaging in issues surrounding Chechnya or Kashmir also have difficulties being accredited, as Russia or India are members of the NGO Committee. Similarly, religious and minority organisations have difficulties being accredited. As NGO representatives estimated, out of ten applications which are discussed, nine of them $(\leftarrow \mathbf{p . ~ 8 4})$ concern human rights $\mathrm{NGOs}^{4}$. In addition, human rights NGOs are the only type of NGOs which are specifically recalled on their purposes when interacting with the UN. As it is phrased in the 1996/31 resolution: "Organisations to be accorded special consultative status because of their interest in the field of human rights should pursue the goals of promotion and protection of human rights in accordance with the spirit of the Charter of the United Nations, the Universal Declaration of Human Rights and the Vienna Declaration and Programme of Action"5.

In short, the consultative status is characterised by a diverse ambivalence. On the one hand, NGOs seek consultative status at the UN because they physically gain access to buildings, delegates, meetings etc. and obtain all kinds of information. Moreover, the consultative status also implies international recognition by governmental authorities. On the other hand, it is an imposed status on the NGOs in that the UN defines the rules of the game and can also retain it. Also, admission of NGOs to consultative status may heavily depend on political consideration. In the following part, consultative status with the UN will be explored on the example of the international human rights NGO International Federation of Human Rights and its national affiliate Human Rights in China in order to show how an NGO is able to overcome obstacles to access.

\section{PIGGY-BACK TO THE UN WITH AN INTERNATIONAL “CARRIER”}

Internationally operating human rights NGOs differ in the composition of their parts. For example, unitary international human rights NGOs, such as Amnesty International, maintain a large international secretariat, which develops and guides the policy of the different national sections. Federative NGOs, instead, function as umbrella organisations for autonomous national NGOs which wish to establish a loose international platform between them to co-ordinate their activities

\footnotetext{
${ }^{4}$ For recent examples of human rights NGOs as cases of discussion concerning their status, see Freedom House, Christian Solidarity International and Transnational Radical Party, all in UN Doc. E/2000/88 (Part II) para.70124. For a good analysis of some cases, see Aston 2001.

${ }^{5}$ In the previous resolution on NGO accreditation, it was similarly laid down, that human rights NGOs "should have a general international concern with this matter, not be restricted to the interests of a particular group of States", see UN Resolution 1296 (XLIV) para. 17.
} 
on the international level ${ }^{6}$. The International Federation of Human Rights is just such a federative NGO in the field of human rights, which comprises today 115 national member leagues.

In the international sphere and in relation to IGOs, federations can play an important role. Most importantly, through the international body, the federation enables its national member NGOs to have a representation on the international level. Being an international organisation, the FIDH, for example, was able to apply for consultative status to the UN even prior to 1996, in fact, it received consultative status at the UN early on, as it was accredited to the IGO in 1952 already. Through its recognition at the UN, it could provide its national member NGOs with a channel to the IGO to advance their aims and concerns on the international level. The federative organisation thus became a mouthpiece for its single members and enabled them to - as a representative phrased it in an interview - "make their voice heard" above the national scheme in which only they otherwise operate. For example, the member NGO of country Xcan take the floor and bring forward accusations against its government on human rights violations. Theseactivities - although $(\leftarrow \mathbf{p . ~ 8 5})$ they may not have immediate direct impact - are very impressive and are intended to have long-term effect on various levels: on the international level, the government is shamed before the international community of states and may need to justify domestic activities. On the domestic level, speeches of national NGOs may have an impact as the national media makes aware of these events what, in return, reaches the country's population and informs them about the activities of their national organisation.

At the same time, however, federations are limited in the extent to which they are able to support their single national NGOs in their international presence. Because the national sections remain autonomous in their decisions, the international federation cannot impose on them the content of their programs. As a consequence, the federative FIDH is also quite vulnerable to losing its status at the UN, because it depends on the compliance of every single league member with the requirements of the consultative status. Thus, the NGO is only as strong as the weakest part in the chain: if one league member violates or breaks a rule, the NGO - as a whole - has to fear losing consultative status. Moreover, federative NGOs are also particularly threatened to be expelled from the status, when a government seeks to go against "its" national member NGO. As mentioned in the general part, the NGO Committee consists of governmental delegates only and decides on NGO related accreditation-matters. In this committee, there are many countries represented which are accused by NGOs of violating human rights. As a result, NGOs engaging in countries with poor human rights records have problems maintaining the consultative status as they are threatened with suspension.

In fact, the FIDH had been frightened with suspension from consultative status at various times in its history of relations with the UN when single league members had problems with their respective governments. An incident, for example, took place in 1982, when a delegation member of the USSR demanded that a representative of the FIDH present the organisation at the UN. The reason for this "order" was the NGO's mission report on human rights violations, in which, among others, the FIDH reported on human rights violations in Russia (Bemheim 1983: 166167). Also during the 1978 review the Argentine representative cited the FIDH, among others, as having attacked certain governments during the Commission on Human Rights in 1977 and in

\footnotetext{
${ }^{6}$ Often, there are historical reasons for federative NGOs. Many federative NGOs were first active on the national level only and merged together later. By the time national NGOs were founded, international co-operation between them was difficult to establish due to a lack of communication means. As a result, these national NGOs joined together only many years or decades later in loose umbrella organisation when international co-operation was easier to establish.
} 
some other sub-commissions by either statements or circulating material (Pei-heng 1981: 188).

Over the last four years, for example, each year the FIDH had to fear that its status would be withdrawn, as single states confronted the NGOs with complaints about its appearance at UN level. Often, in this respect, the NGO has not been confronted with the content of its contributions at UN level; rather, states sought to withdraw its status on the basis that the NGO had violated procedural rules. In 1999, for example, the FIDH was accused of not having explained its policy and modalities of accreditation of its representatives to the Commission on Human Rights (UN Doc. E/1999/109 para. 55). Incidents of such kind are often used by governments to bring forward additional information against the NGO in question. In the $(\leftarrow \mathbf{p . ~ 8 6})$ context of this accusation, for example, other governments stepped in and saw their chance to suspend the FIDH; they accused the NGO of having accredited "terrorists" under its label: the Bahrain government viewed members of the Bahrain member league of the FIDH who are in exile in Damascus as terrorists. Similarly, in 2001, the FIDH had again been accused by the government of Bahrain of having accredited people without having properly checked their identity. The issue was solved by appealing to the FIDH not to repeat such incidents "for the sake of all non-governmental organisations working with the United Nations" (UN Doc. E/2001/8 para. 94-98). Moreover, the government delegate pointed out that - in his view - there was a pattern of violations (for which NGOs can be suspended from consultative status).

Since the opening of the accreditation to the UN to national NGOs in 1996, in fact, having the consultative status of an internationally operating NGO has become even more important for the FIDH and its affiliates. When in 1996 the consultative status was opened to national NGOs, many organisations have been accredited which are significantly supported by "their" home governments, so that many of them are suspected of being government-organised NGOs. As Petrula (2001: 52), a former representative of FIDH noted in a report "[f]ive years after this reform of consultative status, the FIDH noted with concern that, while resolution 1996/31 aimed to increase participation by all NGOs, it appears today that States display the highest degree of reluctance when itcomes to independent human rights NGOs. Some of the provisions in resolution 1996/31 are used in an abusive way by some governments, either to block certain national human rights NGOs that are independent, credible and efficient from making use of consultative status, or to favour access by national pro-government NGOs".

As a result, national NGOs and their contributions are often not considered useful or trustworthy. For example, many new NGOs seek to take a slot during meetings in which NGOs are allowed to make contributions at UN meetings, such as in the sessions of the Commission on Human Rights. As a result, the speakers' list of NGOs gets endless, so that - as one interviewee expressed it - "no one is listening to NGOsanymore" and governmental delegates takelesseffort to take into account the contributions of NGOs. For this reason, often only international NGOs maintain a good standing before the international community of states and their contributions are considered significant.

In reverse, despite the opening of the status to national NGOs, many member NGOs of the FIDH are not able to receive consultative status at the UN individually, because they heavily criticise their governments, which lobby against their accreditation. For this reason, national NGOs continue to rely on a federation to be represented at the UN level. Similarly, many newly founded national human rights NGOs, which seek consultative status now that application is open for national NGOs, will not receive the status due to the resistance of single governments. Therefore, again, international federative NGOs, such as the FIDH, can provide a means for these organisations to access the UN. $(\leftarrow$ p. 87) 
Such "piggy-back" functions, for example, are provided by the federation for the organisation Human Rights in China. HRIC is an NGO founded by Chinese scientists and scholars in 1989. It monitors the implementation of international human rights standards in the People's Republic of China and carries out advocacy work as well as education programs for Chinese inside and outside the country (Human Rights in China 2003). As part of its mission it seeks working together with UN human rights institutions to address systematic violations taking place in China and to also transmit information about the activities of UN human rights mechanisms to people in China (Human Rights In China 2003). Since January 2001, HRIC is an affiliate to the FIDH and works together with the international federation in good cooperation.

Before linking up with the federation, HRIC tried to receive consultative status at the UN but was rejected several times when applying for accreditation. HRIC's motivation for applying for consultative status was to follow the agenda of the UN and treaty bodies closely, to be able to attend the Commission on Human Rights and world conferences, to send its representatives and to make statements. Most importantly, it was felt within the organisation that it is important to express itself in its own name before the UN. The NGO started its consultative status process in 1998 when the file was send to the UN. The administrative procedures took some time as the NGO was asked to clarify some aspects of its application and had to send in additional information, e.g. it had to clarify its usage of the name of Taiwan, to send in a financial statement as well as a list of all the members of the NGO. Finally, its full application was considered in the June 1999 session of the Committee on NGOs.

Since the NGO expected to have a difficult time receiving the status, the NGO representative lobbied in favour of her organisation long before the session took place. She got in touch with several members of the committee and received an extremely strong support from European and U.S. members. She also tried to establish contact with the Cuban and Chinese delegates but was not received in their missions. In addition, the Lebanon and Algerian delegates did not respond to her request. Some other delegates, however, made clear beforehand that Chinese pressure was strong against the application in the weeks before and one delegation even asked another one to ask the NGO to withdraw the application. On 4 June 1999, the session took place during which the application of the NGO was considered. In deference to usual procedures when the case of an NGO is discussed for five to 30 minutes, the case of HRIC surpassed all expectations; its application took six hours and lasted from 12:30 to $6: 30 \mathrm{pm}$. The session had greater attendance than usual and some delegation sent more representatives than to other sessions. For example, China was represented by five delegates instead of two delegates (Human Rights in China 2001).

The Chinese strategy was to prevent the representative of HRIC from taking the floor although it is part of the procedure that NGOs can present their standpoint to allegations made by a country. Immediately after announcing that HRIC was up for $(\leftarrow \mathbf{p . ~ 8 8})$ review, the Chinese delegate stated after having "studied the case of this organisation from many angles" that the NGO would not qualify for any form of consultative status for various reasons (UN Doc. E/1999/109 para. 2426). According to the Chinese government, the NGO should not receive consultative status, because the members of the organisation were living outside China and had not shown concern about the human rights situation in the country they are living in. In particular, so they argued, the majority of them have either never set foot on Chinese soil or have not gone back to China in recent years, and as such, do not know the situation in China (UN Doc. E/1999/109 para. 24$26)^{7}$.

\footnotetext{
${ }^{7}$ The Chairman of the NGO who was present at the meeting spent ten years in a Chinese prison in the $1980 \mathrm{~s}$
} 
He continued that the NGO had done nothing to improve the human rights situation in China, because it, for example, did not do anything when China was hit by great flood and suffered from economic losses in 1998 by which a population of 20 million had been affected. Moreover, the NGO did not react when the Chinese embassy in Yugoslavia was bombed in May 1998 and the diplomatic personnel suffered. The Chinese delegate considered many of the Board members to be criminals who had been punished for their acts and he also accused the NGO of being linked to secessionists in Tibet. Finally, by a vote of 13 to 3, HRIC was not granted consultative status; only France, Ireland and the United States voted in favour of it (UN Doc. E/1999/109 para. 2426).

Despite being rejected for individual consultative status, the NGOs sought to find a channel to address human rights violations in China at UN level. Since it became a member of the international federation in 2001, it was able to participate as its affiliate during the session of the Commission on Human Rights. In 2002, for example, HICR was represented by its director and its UN representative during the Commission on Human Rights through the FIDH and presented its reports.

\section{CONCLUDING REMARKS}

In this paper the boomerang model has been further explored and empirical evidence was provided about interaction of national NGOs with international NGOs in order to bypass obstacles of access to the international scene. For this purpose, the paper was focused on rules and regulations of the accreditation of NGOs to the UN, namely consultative status. On the example of how Human Rights in China linked up with the International Federation of Human Rights, it was shown how a domestic NGO managed to receive access to the UN despite all obstacles. The boomerang model and its perception of how and why national NGOs seek to link up with internationally operating organisations proved to be a helpful guide for this purpose.

To summarise the empirical results, consultative status with the UN is attractive for NGOs as a means of access, because it opens the door to the intergovernmental sphere. An international NGO, such as the International Federation of Human Rights can function as the mouthpiece for its member NGOs when its consultative status becomes a means to express their views and concerns at UN level. That is to say, as $(\leftarrow \mathbf{p . ~ 8 9 )}$ an international NGO it can take a national NGO "piggyback" to the UN, as such was the case with its new affiliate Human Rights In China whose status had been denied. Through its carrier, HRIC thus obtained access to the UN, which had previously been unreachable for the NGO.

\section{REFERENCES}

Anheier, Helmut, Marlies Glasius, and Mary Kaldor, eds. 2001. Global Civil Society. Oxford: Oxford University Press.

Aston, Juris. 2001. "The United Nations Committee on a Non-Governmental Organisations: Guarding the Entrance to a Politically Divided House". European Journal of International Law 12, 5: 943-963.

Bemheim, Jean-Claude. 1983. Rompre le silence. Fédération internationale des droits de

after the first democracy movement during the 1970s in China. 
l'Homme. Montreal: Boreal Express. $(\leftarrow$ p. 90)

Bettati, Mario 1986. La contribution des organisations non gouvernementales à la formation et l'application du droit international. In Les O.N.G. et le Droit International, edited by Mario Bettati and Pierre-Marie Dupuy. Paris: Economia.

Boli, John, and George M. Thomas, eds. 1999. Constructing World Culture: INGOs Since 1875.

Stanford: Stanford University Press.

Bruckmeier, Karl. 1997. NGO-Netzwerke als globale Umweltakteure. In Nachhaltige Entwicklung. Eine Herausforderung an die Soziologie, edited by Karl-Werner Brand. Opladen: Leske and Budrich.

Cook, Helena. 1996. Amnesty International at the United Nations. In "The Conscience of the World" - The Influence of Non-Governmental Organisations in the UN System, edited by Peter Willetts. London: Hurst.

della Porta, Donatella, Hanspeter Kriesi, and Dieter Rucht, eds. 1999. Social Movements in a Globalising World. Chippenham: St. Martin's.

DESA 2003. NGOs in Consultative Status with ECOSOC. NGO Section of the UN Department of Economic and Social Affairs. Available online: (http://www.un.org/esa/coordination/ngo/), accessed 31 July 2003.

Human Rights In China 2001. Maligned \& excluded in a politicised process: HRIC denied consultative status. Available online: (http://www.hrichina.org/crf/english/99fall/el4_excluded.html), accessed 7 May 2001.

Human Rights In China 2003. About HRIC. Available online: (http://www.hrichina.org/hricinfo/about/ html), accessed 14 April 2001.

Keck, Margaret and Kathryn Sikkink. 1998. Activists Beyond Borders. Cornell: Cornell University Press. Khagram, Sanjee, James Riker, and Kathryn Sikkink, eds. 2002. Restructuring World Politics- Transnational Social Movements, Networks, and Norms. Minneapolis: University of Minnesota

Press.

Lagoni, Rainer. 1995. “Article 71”. In The Charter of the United Nations. A Commentary, edited by Bruno Simma. Oxford: Oxford University Press.

Mathews, Jessica. 1997. "Power Shift”. Foreign Affairs 76, 1: 50-66.

Osborne, Stephan, ed. 2000. Public-Private Partnerships. Theory and practice in international perspective. New York: Routledge.

Pei-heng, Chiang. 1981. Non-Governmental Organisations at the United Nations. ldentity, Role and Functions. New York: Praeger. 
Petrula, Eleni. 2001. "The United Nations Opens the Door to GONGOs". In Human Rights Defenders on the Front Line-Annual Report 2000, edited by The Observatory for the Protection of Human Rights. The Observatory for the Protection of Human Rights.

Risse-Kappen, Thomas, ed. 1995. Bringing Transnational Relations Back In: Non-State Actors, Domestic Structures and International Institutions. Cambridge: Cambridge University Press.

Ritchie, Cyril. 1996. "Coordinate? Cooperate? Harmonise? NGO Policy and Operational Coalitions". In NGOs, the UN, and Global Governance, edited by Thomas Weiss and Leon Gordenker. Boulder: Lynne Rienner.

Salamon, Lester. 1994. "The Rise of the Nonprofit Sector”. Foreign Affairs 73, 4: 109-122.

Smith, Jackie. 2002. "Strategic Framing and Solidarity in Transnational Social Movement Organisations”. International Sociology 17, 4: 505-528.

Smith, Jackie, Charles Chatfield, and Ron Pagnucco, eds. 1997. Transnational Social Movements and Global Politics-Solidarity Beyond the State. Syracuse: Syracuse University Publication.

Smith, Jackie, Ron Pagnucco, and George Lopez. 1998. "Globalising Human Rights: The Work of Transnational Human Rights NGOs in the 1990s". Human Rights Quarterly 20(2): 396-397.

UN Doc. E/1998/43. Work of the Non-Governmental Organisations Section of the Secretariat (8 May 1998).

UN Doc. E/1999/109. Report of the Committee on Non-Governmental Organisations on its 1999 Session (15 July 1999).

UN Doc. E/2001/8. Report of the Committee on Non-Governmental Organisations on its resumed 2000 regular session (22 February 2001).

UN Resolution 1296 (XLIV). Arrangement for Consultation with Non-Governmental Organisations

(23 May 1960).

Vaillancourt, Pauline. 2000. Public-Private Policy Partnerships. Cambridge: MIT Press.

Weschler, Joanna 1998. Non-Governmental Human Rights Organisations, Polish Quarterly of International Affairs 7, 3: 137-154. 